In the presence of urea or soyabean protein, bacterial protein synthesis was further increased.

With untreated barley, urea was less efficient than soyabean for this synthesis, but approached soyabean value when the barley was treated.

The decreased $\mathrm{N}$ efficiency of the diet (ZeLTER and CharLet-Lery, 1972) probably arising from the lower availability could limit the benefits of the barley treatment observed at the abomasum level. A study of the nature and amount of amino acids absorbed at the gut level could allow to decide whether this treatment is adequate.

\title{
DIGESTION DES PROTÉINES DE CÉRÉALES CHEZ L'AGNEAU EN CROISSANCE
}

\author{
R. PION, C. CHAMPREDON et P. THIVEND * \\ Laboratoire d'études du Métabolisme azoté, \\ * Station de Recherches sur l'Élevage des Ruminants, \\ Centre de Recherches de Clermont Ferrand, I. N. R. A., \\ Theix 63110 Beaumont
}

Nous avons étudié la composition des contenus digestifs d'agneaux en croissance ayant reçu des régimes comportant diverses céréales (VERMorel et al., 1970).

Des échantillons moyens de contenus de caillette et de gros intestin prélevés à l'abattage sont constitués à partir de trois lots d'animaux ayant reçu des régimes renfermant respectivement du maiss, du blé et de l'orge ; les céréales représentaient environ 70 p. Ioo des régimes, qui comportaient en outre environ $20 \mathrm{p}$, Ioo de farine de luzerne et du tourteau de soja.

Les matières azotées hydrosolubles sont extraites après neutralisation, et séparées des résidus par centrifugation ( $35000 \mathrm{~g}, \mathrm{I} \mathrm{h}$ ). Les résidus subissent une extraction par l'éthanol $60 \mathrm{p}$. roo, puis par l'acide trichloracétique à ıo p. Ioo (ATC). Les extraits aqueux sont analysés par filtration sur gel Sephadex G 25 ; les différents pics sont localisés par l'enregistrement de l'absorption à $280 \mathrm{~m} \mu$ et par la détection des $\mathrm{NH}_{2}$ libres par réaction avec la ninhydrine. Les acides aminés des différentes fractions sont dosés par chromatographie sur colonne.

Des échantillons des céréales utilisées pour la constitution des régimes sont analysés dans les mêmes conditions, après avoir été mis en suspension dans une solution d'HCl diluée, de manière à les amener à un $\mathrm{pH}$ voisin de celui des contenus de caillette.

Dans ces conditions, l'extraction éthanolique n'a pas solubilisé la totalité des prolamines des céréales, puisque les extraits obtenus ne renferment que de I 8 à $25 \mathrm{p}$. Ioo des matières azotées des graines. C'est pourquoi nous avons comparé les résultats obtenus sur les contenus digestifs à ceux de ces analyses, et non à la composition en protéines des céréales étudiées.

Les compositions en acides aminés des résidus d'extraction permettent de supposer qu'une partie au moins des prolamines qui ne sont pas extraites par l'alcool se trouve dans les résidus d'extraction, au moins dans le cas du mais.

Une partie de leurs acides aminés peut se trouver sous forme libre ou dans des peptides plus ou moins longs dans les extraits aqueux, ainsi qu'en témoigne la teneur élevée en leucine par rapport à celle de l'extrait aqueux de maïs de la fraction hydrosoluble des contenus de caillette des animaux ayant consommé cette céréale. La comparaison des teneurs en lysine de ces deux extraits ne permet pas d'aboutir à la même conclusion en ce qui concerne cet acide aminé. 
Les compositions en acides aminés des résidus d'extraction de contenus de caillette permettent de supposer que ces derniers ne renferment pas de quantités très importantes de prolamines.

L'ensemble de ces résultats montre qu'il doit y avoir une digestion importante dans le rumen des prolamines des céréales étudiées, mais que cette dernière n'a pas abouti à la libération de tous leurs acides aminés, et qu'une partie de ceux-ci doit se trouver sous forme peptidique dans le rumen.

Les proportions de matières azotées qui sont solubles dans l'ATC restent faibles dans tous les cas.

Le fractionnement sur sephadex des extraits aqueux met en évidence la disparition à la suite de la digestion dans le rumen du pic correspondant aux protéines dans le cas des céréales.

Les contenus du gros intestin diffèrent des contenus de caillette par la présence d'une plus forte proportion de matières azotées solubles dans l'éthanol, et d'une plus faible proportion de matières azotées hydrosolubles.

La teneur en leucine de l'extrait aqueux du contenu du gros intestin des animaux qui ont reçu le régime à base de maïs est faible, et à peine supérieure à la moitié de celle qui était observée dans le cas du contenu de caillette. Il semble que cette différence soit trop importante pour pouvoir s'expliquer par une simple dilution des composés riches en leucine présents dans la caillette dans d'autres matières azotées solubles, et traduise une disparition au moins partielle des ces composés.

Les extraits éthanoliques des contenus de gros intestins ont une composition en acides aminés très différente de celle des extraits correspondants obtenus à partir des contenus de caillettes.

Il semble toutefois possible, compte tenu des teneurs relativement faibles en lysine et relativement élevées en leucine observées dans le cas du maïs, que la zéine trouvée dans la caillette se trouve diluée dans d'autres protéines dans le contenu du gros intestin correspondant.

\section{RÉFÉRENCE BIBLIOGRAPHIQUE}

Vermorel M., Thivend P., Theriez M., I97o. Utilisation énergétique de l'orge, du blé, du maïs et du sorgho par l'agneau en croissance. Ann. Zootech., 19, 461-464.

\section{SUMMARY}

\section{DIGESTION OF CEREAL PROTEINS IN THE GROWING LAMB}

The composition of digestive contents in the growing lamb fed diets including different cereals was studied (VERMOREL et al., 1970). Mean samples of abomasum and large intestine contents taken after slaughtering were constitued from 3 lots of animals fed diets including maize, wheat and barley respectively. The cereals represented $70 \mathrm{p}$. 100 of the diets that also contained about $20 \mathrm{p}$. Ioo of lucerne meal and soyabean oil-meal.

Hydrosoluble nitrogenous matters were extracted after neutralization and separated from insolubles by centrifugation ( $35000 \mathrm{~g}, \mathrm{I} \mathrm{h}$ ). Insolubles were extracted with $60 \mathrm{p}$. I00 Ethanol, then with ro p. Ioo TCA. Aqueous extracts were analysed after filtration through G25 sephadex gel ; the different peaks were located by recording of the $280 \mathrm{~m} \mu$ absorption and following detection of the free $\mathrm{NH}_{2}$ after reaction with nynhydrine. The amino acids of the different fractions were analysed by column chromatography.

Samples of the cereals used in the diets were analysed in the same conditions, after they had been put in suspension into diluted $\mathrm{HCl}$, so that they were brought to a $\mathrm{pH}$ close to that of the abomasum contents. 
In this case, ethanolic extraction did not dissolve all cereal prolamines, since the obtained extracts only contained $\mathrm{I} 8$ to $25 \mathrm{p}$. Ioo of the crude protein of the seeds. That is why we compared the results obtained in digestive contents to those of analyses, and not to the protein composition of the studied cereals.

The amino acid compositions of the extraction insolubles led us to suggest that at least one part of the prolamines that were not extracted with ethanol, was recovered in the extraction insolubles, at least in the case of maize.

Part of their aminoacids can be free or included in more or less long chain peptides in the aqueous extracts, as shown by the high amount of leucine as compared to that in the maize aqueous extract of the hydrosoluble fraction of the abomasum contents in the animals fed that cereal. Comparison of the lysine content of those two extracts does not lead to the same conclusion respecting this amino acid.

Because of the amino acid compositions of the extraction insolubles in the abomasum contents, it can be supposed that these insolubles do not contain very large quantities of prolamines.

All these results show that in the rumen there might be an important digestion of the studied cereal prolamines, but that this digestion does not lead to release of all their amino acids, and that some of them must be recovered as peptides in the rumen.

The proportions of TCA soluble nitrogenous matters were low in all cases.

The separation of the aqueous extracts through sephadex showed the disappearance after digestion in the rumen of the peak corresponding to the proteins in the case of cereals.

The large intestine contents were different from those of the abomasum because of a higher proportion of soluble nitrogenous matters in ethanol and of a lower proportion of hydrosoluble matters.

The amount of leucine in the aqueous extract of the large intestine content of the animals fed the maize diet was low and exceeded only by scarcely the half that observed in the abomasum content. This difference seems to be too large to be explained only by a dilution in other soluble nitrogenous matters of the leucine rich components in the abomasum and accounts for a disappearance of at least part of those components.

Ethanolic extracts of the large intestine contents showed an amino acid composition very different from that of the corresponding extracts obtained from the abomasum contents.

However, it seems possible, according to the relatively low lysine and high leucine amounts observed in the maize diet, that the zein found in the abomasum is diluted in other proteins in the corresponding content of the large intestine.

\title{
ÉTUde DU MÉTABOLISME DE LA MÉTHIONINE DANS LE RUMEN DE LA GHÈVRE
}

\author{
C. CHAMPREDON, R. PION et J. PRUGNAUD \\ Laboratoire d'Étude du Métabolisme azoté, \\ Centre de Recherches de Clermont Ferrand, I. N. R. A., \\ Theix 63110 Beaumont
}

A fin de connaitre l'utilisation digestive de la méthionine chez le ruminant, deux chèvres (33 et $36 \mathrm{~kg}$ ), porteuses d'une canule de la caillette, ont reçu par injection intraruminale, I h $3^{\circ}$ après la distribution du repas du matin, $2 \mathrm{~m}$ Curie de L-Méthionine ${ }^{95} \mathrm{~S}$ en présence de $2,5 \mathrm{~g}$ de 